\title{
Hydrogel platform for in vitro three-dimensional assembly of human stem cell-derived $\beta$ cells and endothelial cells
}

Punn Augsornworawat ${ }^{1,2,3}$, Leonardo Velazco-Cruz ${ }^{1,3}$, Jiwon Song ${ }^{1}$, and Jeffrey R. Millman ${ }^{1,2^{*}}$

${ }^{1}$ Division of Endocrinology, Metabolism and Lipid Research

Washington University School of Medicine

Campus Box 8127

660 South Euclid Avenue

St. Louis, MO 63110

USA

${ }^{2}$ Department of Biomedical Engineering

Washington University in St. Louis

1 Brookings Drive

St. Louis, MO 63130

USA

${ }^{3}$ These authors contributed equally

*To whom correspondence should be addressed:

Jeffrey R. Millman, jmillman@wustl.edu, 314.362.3268 (phone), 314.362 .8265 (fax) 


\section{Abstract}

Differentiation of stem cells into functional replacement cells and tissues is a major goal of the regenerative medicine field. However, one limitation has been organization of differentiated cells into multi-cellular, three-dimensional assemblies. The islets of Langerhans contain many endocrine and non-endocrine cell types, such as insulin-producing $\beta$ cells and endothelial cells. Transplantation of exogenous islets into diabetic patients can serve as a cell replacement therapy, replacing the need for patients to inject themselves with insulin, but the number of available islets from cadaveric donors is low. We have developed a strategy of assembling human embryonic stem cell-derived $\beta$ cells with endothelial cells into three-dimensional aggregates on a hydrogel. The resulting islet organoids express $\beta$ cell markers and are functional, capable of undergoing glucose-stimulated insulin secretion. These results provide a platform for evaluating the effects of the islet tissue microenvironment on human embryonic stem cell-derived $\beta$ cells and other islet endocrine cells to develop tissue engineered islets.

\section{Keywords}

Stem cells; tissue engineering; organoids; diabetes; biomaterials 


\section{Introduction}

In diabetes, insulin-producing $\beta$ cells, which are located within islets of Langerhans in the pancreas, are dysfunctional or destroyed by high levels of metabolites, such as glucotoxicity or lipotoxicity, or by autoimmune attack. The rapid rise in diabetes prevalence has generated much attention towards the development of technologies to better study and treat this disease. However, there is no cure for diabetes, and current treatments are insufficient in controlling the disease for many patients. A small number of patients have been transplanted with cadaveric human islets, which contain $\beta$ cells, and remained insulin independent for years [1]. Unfortunately this approach is limited because of the scarcity and variability of isolated human islets available for patients, whom often require islets from multiple donors to achieve normal blood sugar levels [2].

Several reports by us and others have detailed approaches for making insulin-producing $\beta$-like cells from human embryonic stem cells (hESCs) with the goal that these cells could be used for both cell replacement therapy and drug screening for diabetes [3-8]. These hESC-derived $\beta$ (SC- $\beta$ ) cells are capable of undergoing glucose-stimulated insulin secretion and express markers found in $\beta$ cells. While current methodologies produce final cell populations containing SC- $\beta$ cells, the cellular composition is significantly different than islets found within the body. Current SC- $\beta$ cell differentiations create cellular clusters that, while visually resembling islets and having functional SC- $\beta$ cells that are electrically coupled according to $\mathrm{Ca}^{2+}$ flux measurements [4], differ significantly from human islets. The differentiation process does produce cells expressing hormones indicative of other islet endocrine cell types, glucagon and somatostatin, but endothelial cells (ECs) are absent. The native islet microenvironment, which is influenced in part by ECs, is highly specialized in supporting islet architecture and function [9]. This three-dimensional islet environment facilitates $\beta$ cell- $\beta$ cell and $\beta$ cellEC interactions which altogether support $\beta$ cell survival and insulin secretion. Specifically, ECs produce extracellular matrix (ECM) proteins to provide such interactions [10, 11].

Modulating the microenvironment that SC- $\beta$ cells experience to be more islet-like is technologically challenging with current approaches. As SC- $\beta$ cells are derived from endoderm and endothelial cells from mesoderm germ layers, robust simultaneous differentiation of both cell types in 
the same culture is not possible. This is because current differentiation protocols specify only one germ layer. Approaches focused on assembly of multiple cell types during or after differentiation are therefore preferable. However, currently culture of aggregates containing SC- $\beta$ cells in suspension is commonly performed on shaker plates or spinner flasks [5], which requires expensive water-, heat-, and $\mathrm{CO}_{2-}$ resistant equipment and expertise with hESC culture in reactors, or on air-liquid-interfaces [12], which requires manual formation of each individual aggregate and are not amenable to addition of islet components.

Here we established a platform for the assembly of islet like organoids with SC- $\beta$ cells and ECs. These parameters allow for SC- $\beta$ cells to assemble and interact with ECs in microtubule networks when cultured on Matrigel. The heterozygous cell assembles express markers found in islets and are capable of undergoing glucose-stimulated insulin secretion. In contrast, SC- $\beta$ cells and ECs did not assemble when plated in two-dimensional culture on standard tissue culture plastic, in suspension, nor on collagen 1 hydrogels. Such assembly mimics the vascular architect found in native islets, which allows for in vitro based investigations relating to $\beta$ cell interactions within the microenvironment.

\section{Materials and methods}

\subsection{Stem cell culture}

The HUES8 hESC line was generously provided by Dr. Douglas Melton (Harvard University) and has been previously published $[4,5]$. These cells were cultured in an undifferentiated state in mTeSR1 (StemCell Technologies; 05850) in 100-mL or 30-mL spinner flasks (REPROCELL; ABBWVS10A or ABBWVS03A) on a stirrer plate (Chemglass) set at 60 RPM in a humidified incubator set at $5 \% \mathrm{CO}_{2}$ and $37^{\circ} \mathrm{C}$. Accutase (StemCell Technologies; 07920) was used to passage cells every 3 d. The Vi-Cell XR (Beckman Coulter) was used to quantify viable cell counts and $6 \times 10^{5}$ cells $/ \mathrm{mL}$ in mTeSR1+ $10 \mu \mathrm{M}$ Y27632 (Abcam; ab120129) were seeded back into the flasks.

\subsection{Differentiation to $S C-\beta$ cells}


Differentiation was performed as described by Velazco-Cruz et al [5]. Undifferentiated hESCs were seeded into 30-mL spinner flasks, cultured for $3 \mathrm{~d}$ in mTeSR1, and then cultured in the following conditions in order:

Stage 1: 3 days in S1 basal media with $100 \mathrm{ng} / \mathrm{ml}$ Activin A (R\&D Systems; 338-AC) and $3 \mu \mathrm{M}$ CHIR99021 (Stemgent; 04-0004-10) for 1 day followed by S1 basal media with $100 \mathrm{ng} / \mathrm{ml}$ Activin A for 2 days.

Stage 2: 3 days in S2 basal media with 50 ng/ml KGF (Peprotech; AF-100-19).

Stage 3: 1 day in S3 basal media with 50 ng/ml KGF, 200 nM LDN193189 (Reprocell; 040074), 500 nM

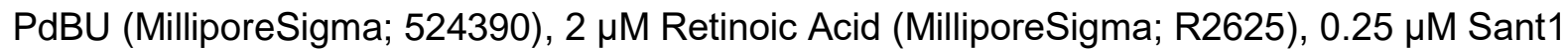
(MilliporeSigma; S4572), and $10 \mu \mathrm{M}$ Y27632.

Stage 4: 5 days in S3 basal media with $5 \mathrm{ng} / \mathrm{mL}$ Activin A, $50 \mathrm{ng} / \mathrm{mL}$ KGF, $0.1 \mu \mathrm{M}$ Retinoic Acid, 0.25 $\mu \mathrm{M}$ SANT1, and $10 \mu \mathrm{M}$ Y27632.

Stage 5: 7 days in S5 basal media with $10 \mu \mathrm{M}$ ALK5i II (Enzo Life Sciences; ALX-270-445-M005), 20 $\mathrm{ng} / \mathrm{mL}$ Betacellulin (R\&D Systems; 261-CE-050), $0.1 \mu \mathrm{M}$ Retinoic Acid, $0.25 \mu \mathrm{M}$ SANT1, $1 \mu \mathrm{M}$ T3 (Biosciences; 64245), and $1 \mu \mathrm{M} \mathrm{XXI} \mathrm{(MilliporeSigma;} \mathrm{595790).} \mathrm{At} \mathrm{the} \mathrm{end} \mathrm{of} \mathrm{this} \mathrm{stage,} \mathrm{clusters} \mathrm{were}$ reaggregated by dispersion with TrypLE Express (ThermoFisher; 12604013) and replating in a 6-well plate on an Orbi-Shaker (Benchmark).

Stage 6: 12-22 days in enhanced serum-free media (ESFM).

The basal media formulations are as follows:

S1 basal media: 500 mL MCDB 131 (Cellgro; 15-100-CV) plus 0.22 g glucose (MilliporeSigma; G7528), $1.23 \mathrm{~g}$ sodium bicarbonate (MilliporeSigma; S3817), $10 \mathrm{~g}$ bovine serum albumin (BSA) (Proliant; 68700), $10 \mu \mathrm{L}$ ITS-X (Invitrogen; 51500056), 5 mL GlutaMAX (Invitrogen; 35050079), 22 mg vitamin C (MilliporeSigma; A4544), and $5 \mathrm{~mL}$ penicillin/streptomycin (P/S) solution (Cellgro; 30-002-CI). S2 basal media: $500 \mathrm{~mL}$ MCDB 131 plus $0.22 \mathrm{~g}$ glucose, $0.615 \mathrm{~g}$ sodium bicarbonate, $10 \mathrm{~g} \mathrm{BSA}, 10 \mu \mathrm{L}$ ITS-X, $5 \mathrm{~mL}$ GlutaMAX, $22 \mathrm{mg}$ vitamin $\mathrm{C}$, and $5 \mathrm{~mL}$ P/S. 
S3 basal media: $500 \mathrm{~mL}$ MCDB 131 plus $0.22 \mathrm{~g}$ glucose, $0.615 \mathrm{~g}$ sodium bicarbonate, $10 \mathrm{~g} \mathrm{BSA}, 2.5$ $\mathrm{mL}$ ITS-X, $5 \mathrm{~mL}$ GlutaMAX, $22 \mathrm{mg}$ vitamin C, and $5 \mathrm{~mL}$ P/S.

S5 media: $500 \mathrm{~mL}$ MCDB 131 plus $1.8 \mathrm{~g}$ glucose, $0.877 \mathrm{~g}$ sodium bicarbonate, $10 \mathrm{~g}$ BSA, $2.5 \mathrm{~mL}$ ITSX, $5 \mathrm{~mL}$ GlutaMAX, $22 \mathrm{mg}$ vitamin C, $5 \mathrm{~mL}$ P/S, and $5 \mathrm{mg}$ heparin (MilliporeSigma; A4544).

ESFM: $500 \mathrm{~mL}$ MCDB 131 plus $0.23 \mathrm{~g}$ glucose, $10.5 \mathrm{~g}$ BSA, $5.2 \mathrm{~mL}$ GlutaMAX, $5.2 \mathrm{~mL}$ P/S, $5 \mathrm{mg}$

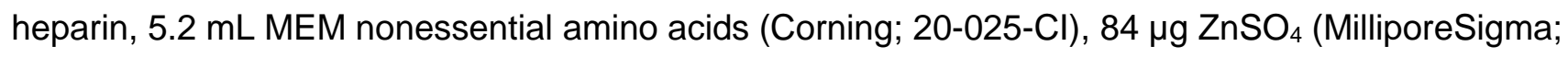
10883), $523 \mu \mathrm{L}$ Trace Elements A (Corning; 25-021-Cl), and $523 \mu \mathrm{L}$ Trace Elements B (Corning; 25022-Cl).

\subsection{Light microscopy}

Images of cell clusters stained with $2.5 \mu \mathrm{g} / \mathrm{mL}$ DTZ (MilliporeSigma; 194832) were taken with an inverted light microscope (Leica DMi1).

\subsection{Immunohistochemistry}

Clusters were fixed with 4\% paraformaldehyde (Electron Microscopy Science; 15714) overnight at $4{ }^{\circ} \mathrm{C}$, embedded in Histogel (Thermo Scientific; hg-4000-012), and paraffin-embedded and sectioned by the Division of Comparative Medicine (DCM) Research Animal Diagnostic Laboratory Core at Washington University. Immunostaining was performed by paraffin removal with Histoclear (Thermo Scientific; C78-2-G), rehydration by treatment with increasing ratios of water to ethanol, antigens retrieved by treatmetn with 0.05 M EDTA (Ambion; AM9261) in a pressure cooker (Proteogenix; 2100 Retriever). Non-specific antibody binding was blocked with a 30-min treatment in staining buffer (5\% donkey serum (Jackson Immunoresearch; 017-000-121) and 0.1\% Triton-X 100 (Acros Organics; 327371000) in PBS), followed by overnight staining with 1:300 dilutions of rat-anti-C-peptide (DSHB; GN-ID4-S) and mouse-anti-glucagon (ABCAM; ab82270) primary antibodies. Samples were stained with donkey secondary antibodies containing Alexa Fluor fluorophores (Invitrogen) for $2 \mathrm{hr}$ at $4{ }^{\circ} \mathrm{C}$, and treated with DAPI in the mounting solution Fluoromount-G (SouthernBiotech; 0100-20). Imaging was performed on a Nikon A1Rsi confocal microscope. 


\subsection{Assembly of SC- $\beta$ cells and ECs in suspension}

Human umbilical vein endothelial cells (HUVECs) were purchased form Lonza (C2519A) and cultured in EGM-2 media (Lonza; CC-3162). HUVECs and Stage 6 clusters containing SC- $\beta$ cells were dispersed with TripLE Express and plated into a 6-well plate on an Orbi-Shaker at $100 \mathrm{rpm}$. Two conditions were tested: $3 \times 10^{6}$ Stage 6 cells only (control) and $2.5 \times 10^{6}$ Stage 6 cells mixed with $0.5 \times 10^{6}$ HUVECs. Cells were cultured in a media of $90 \%$ ESFM and $10 \%$ EGM-2. The presence of these cell types was assessed after $48 \mathrm{hr}$ by dispersion and plating into a 96-well plate followed by immunostaining.

\subsection{Whole-mount immunostaining}

Cell assemblies were fixed within the well using $4 \%$ paraformaldehyde treatment overnight at 4 ${ }^{\circ} \mathrm{C}$. Non-specific antibody binding was blocked with a 30 -min treatment in staining buffer (5\% donkey serum (Jackson Immunoresearch; 017-000-121) and 0.1\% Triton-X 100 (Acros Organics; 327371000) in PBS) followed by overnight staining with 1:300 dilutions of rat-anti-C-peptide (DSHB; GN-ID4-S) and mouse-anti-CD31 (Dako; M082329-2) primary antibodies. Samples were stained with donkey secondary antibodies containing Alexa Fluor fluorophores (Invitrogen) for $2 \mathrm{hr}$ at $4{ }^{\circ} \mathrm{C}$ and treated with DAPI. Imaging was performed on a Nikon A1Rsi confocal microscope.

\subsection{Assembly of SC- $\beta$ cells and ECs in two-dimensional culture}

HUVECs and Stage 6 clusters containing SC- $\beta$ cells were dispersed with TripLE Express and plated ( $1 \times 10^{5}$ cells each) into a 96 -well plate. Cells were cultured in a media of $90 \%$ ESFM and $10 \%$ EGM-2. After $24 \mathrm{hr}$, the cells were fixed with 4\% paraformaldehyde for immunostaining assessment of both cell types.

\subsection{Assembly of SC- $\beta$ cells and ECs on collagen 1 and Matrigel}


Cold Matrigel (Fisher; 356230; $60 \mu \mathrm{L}$ ) was transferred into 96-well plates and then incubated at $37^{\circ} \mathrm{C}$ for $1 \mathrm{hr}$ to create gel slabs. Collagen 1 (ThermoFisher; $\mathrm{A} 1048301 ; 60 \mu \mathrm{L}$ ) at $4 \mathrm{mg} / \mathrm{mL} \mathrm{pH}$ neutralized, transferred into 96-well plates, and incubated at RT for 1 min to create gel slabs. After this time, HUVECs and Stage 6 clusters containing SC- $\beta$ cells were dispersed with TripLE Express and plated on top of the gel slabs over a range of cell numbers $\left(0.5-2 \times 10^{5}\right.$ Stage 6 and $0-1.5 \times 10^{5}$ HUVECs). Cells were cultured in a media of 90\% ESFM and 10\% EGM-2. After $24 \mathrm{hr}$, the cells were fixed with $4 \%$ paraformaldehyde for immunostaining assessment of both cell types.

\subsection{Glucose-stimulated insulin secretion assay}

This assay was performed by first washing cells twice with $\mathrm{KRB}$ buffer (128 mM NaCl, $5 \mathrm{mM}$ $\mathrm{KCl}, 2.7 \mathrm{mM} \mathrm{CaCl}_{2} 1.2 \mathrm{mM} \mathrm{MgSO}_{4}, 1 \mathrm{mM} \mathrm{Na}_{2} \mathrm{HPO}_{4}, 1.2 \mathrm{mM} \mathrm{KH}_{2} \mathrm{PO}_{4}, 5 \mathrm{mM} \mathrm{NaHCO}, 10 \mathrm{mM} \mathrm{HEPES}$ (Gibco; 15630-080), and 0.1\% BSA) and equilibrating cells in $2 \mathrm{mM}$ glucose KRB for a $1 \mathrm{hr}$. The supernatant was removed and replaced with fresh $2 \mathrm{mM}$ glucose $\mathrm{KRB}$, discarding the old KRB solution. Assemblies were incubated for $1 \mathrm{hr}$, the supernatant removed and replaced with fresh $20 \mathrm{mM}$ glucose $\mathrm{KRB}$, retaining the old $\mathrm{KRB}$ solution. The assemblies were incubated for $1 \mathrm{hr}$, the supernatant removed and retained. Insulin concentration with the retained KRB supernatant was quantified with a Human Insulin ELISA (ALPCO; 80-INSHU-E10.1). Secretion was normalized to cell counts by single-cell dispersing assemblies with 10-min TrypLE Express treatment and quantifying viable cell count with a Vi-Cell XR.

\subsection{Real-time PCR}

The RNeasy Mini Kit (Qiagen; 74016) with DNase treatment (Qiagen; 79254), was used to extract RNA from cell assemblies. The High Capacity cDNA Reverse Transcriptase Kit (Applied Biosystems; 4368814) was used to make cDNA for gene expression measurements. Real-time PCR was performed with a StepOnePlus (Applied Biosystems) instrument using PowerUp SYBR Green Master Mix (Applied Biosystems; A25741). Analysis was performed using $\Delta \Delta \mathrm{Ct}$ methodology and normalization to TBP. The following primer pairs used: CAATGCCACGCTTCTGC, 
TTCTACACACCCAAGACCCG; PDX1, CGTCCGCTTGTTCTCCTC, CCTTTCCCATGGATGAAGTC;

TBP, GCCATAAGGCATCATTGGAC, AACAACAGCCTGCCACCTTA; NKX6-1,

CCGAGTCCTGCTTCTTCTTG, ATTCGTTGGGGATGACAGAG; $\underline{\text { HGA }}$,

TGACCTCAACGATGCATTTC, CTGTCCTGGCTCTTCTGCTC; NEUROD1,

ATGCCCGGAACTTTTTCTTT, CATAGAGAACGTGGCAGCAA; NX2-2,

GGAGCTTGAGTCCTGAGGG, TCTACGACAGCAGCGACAAC; GCK, ATGCTGGACGACAGAGCC, CCTTCTTCAGGTCCTCCTCC; $\underline{\text { MAFB, }}$ CATAGAGAACGTGGCAGCAA, ATGCCCGGAACTTTTTCTTT.

\subsection{Statistical analysis}

GraphPad Prism was used to determine statistical significance using two-sided unpaired and paired $t$-tests. Data is represented as mean \pm SEM.

\section{Results}

\subsection{Development of platform for SC- $\beta$ cells and EC assembly}

We have previously published a protocol for the generation of SC- $\beta$ cells from hESCs [5] (Fig. 1A). This approach is done entirely in suspension culture with the cells grown as aggregates (Fig. 1BC). Specific growth factors and molecules are given in different combinations as differentiation progresses to recapitulate pancreatic development. At the end of the protocol, we generate populations of cells that expression C-peptide and other islet hormones, including glucagon (Fig. 1D).

While this differentiation protocol produces SC- $\beta$ cells, ECs are absent, in contrast to what is seen in native human islets. In order to develop a platform that enables study of SC- $\beta$ cells and ECs, we first attempted to disperse the SC- $\beta$ cell clusters our protocol normally generates, mix with a single cell dispersion of ECs, and allow them to spontaneously reaggregate in a 6-well plate on an orbital shaker at $100 \mathrm{rpm}$, as we have used to previously reaggregated SC- $\beta$ cell clusters [5] (Fig. 2). The morphology of the resulting clusters was unaffected by the inclusion of ECs (Fig. 2A). To check for the 
incorporation of ECs, we dispersed and plated the reaggregated clusters, then stained for C-peptide, a $\beta$ cell marker produced by the insulin gene, and CD31, an endothelial cell marker (Fig. 2B). We observed little to no CD31+ cells, indicating this approach did not enable ECs to be incorporated with the SC- $\beta$ cell clusters. In a separate experiment, we plated a single-cell dispersion of SC- $\beta$ cells mixed with ECs on the bottom of a multi-well plate and assessed with immunostaining (Fig. 3). While we were able to observe many C-peptide+ and CD31+ cells, these populations tended to segregate away from each other, with physical proximity of the populations being observed only in rare instances.

\subsection{Hydrogel platform enables SC- $\beta$ cells and EC assembly}

After observing the difficulty of facilitating C-peptide+ and CD31+ cell physical association, we turned to assembly on top of hydrogels (Fig. 4). Two common commercially available hydrogels were assessed: Rat tail-derived collagen 1 and Matrigel, which is a protein mixture derived from mouse sarcoma cells that consists in part of basement membrane extracellular matrix proteins. After creating slabs of each of the polymerized hydrogels, a mixture of single-cell dispersed SC- $\beta$ cells and ECs at varying ratios was dispensed on top, and assembly of cells observed after $24 \mathrm{hr}$. At all cell ratios tested, no notable cell aggregates were observed with collagen 1. However, on Matrigel, both 1:1 and 3:1 ratios of SC- $\beta$ cell to EC produced three-dimensional structures reminiscent of microtubule networks [13]. Higher ratios of ECs tended to produce more sheet-like morphologies, similar to what was observed with collagen I. SC- $\beta$ cells without endothelial cells produced small aggregates, which is interesting because this did not require the normal equipment used for SC- $\beta$ cell culture and aggregation: Stirrer, shakers, and/or spinner flasks. Taken together, these data demonstrate that threedimensional assembly of SC- $\beta$ cells and ECs can be achieved using polymerized Matrigel with a cell ratio of $1: 1$ to $3: 1$.

\subsection{Characterization of islet organoids}

To characterize islet organoid assembly using our developed platform, we whole-mount stained the resulting aggregate and imaged it with confocal microscopy (Fig. 5). We confirmed that the 
microtubule was formed by the ECs (CD31+) cells. We also observed that the C-peptide+ cells were mostly present on top of the resulting microtubule network, with a few non-assembled C-peptide+ cells observed. Based on our prior observation of the dispersed nature of SC- $\beta$ cell clusters on Matrigel in the absence of ECs (Fig. 4), it is likely that the ECs are secreting pro-migratory factors that attract SC- $\beta$ cells to the microtubule network.

To evaluate the potential of this platform for islet organoid assembly for evaluating islet microenvironment parameters, we performed a glucose-stimulated insulin secretion assay of SC- $\beta$ cell/EC assemblies (Fig. 6). The normal physiological function of pancreatic $\beta$ cells in the body is to secrete insulin in response to high glucose stimulation. This in vitro assay involves treating cells first with low (2 mM) glucose for an hour, collecting the resulting supernatant, then subsequently treating cells with high (20 mM) glucose for an hour, collecting the resulting supernatant, and quantifying the amount of insulin released with ELISA. Testing three independent replicates of the islet organoid assembly revealed all three were robustly functional by secreting higher insulin at high glucose $(p<0.01$; two-way paired $t$-test). On average, insulin secretion increased by $3.9 \pm 0.3 x$ by high glucose stimulation. These data show that the assembled islet organoids are glucose-responsive and secrete insulin.

Finally, we evaluated our SC- $\beta$ cell/EC assemblies by expression of $\beta$ cell genes (Fig. 7). Key genes associated with $\beta$ cell identity, including insulin (INS), transcription factors (MAFB, PDX1, NKX61, NKX2-2, NEUROD1), and with function (CHGA, GCK) were all highly expressed in our assembled islet organoids compared to undifferentiated hESC controls. These data show that SC- $\beta$ cell assemblies made with our platform express $\beta$ cell markers.

\section{Discussion}

The islets of Langerhans are complex, multicellular tissues that are responsible for maintaining glucose tolerance within humans through their ability to sense glucose and secrete hormones. Islets consist of $\beta$ cells and other endocrine cell types along with ECs. Here we developed a platform that enables the assembly of SC- $\beta$ cells with ECs. The assembled heterogenous cell mixture were capable of undergoing glucose-stimulated insulin secretion, a key $\beta$ cell functional feature, and expressed a 
panel of $\beta$ cell genes that are associated with its identity and function. We encountered difficulties successfully assembling SC- $\beta$ cells with ECs using other approaches, indicating that the conditions for this phenotype are limited. Specifically, we found the plating on top of hydrogels made from Matrigel and a SC- $\beta$ cell to EC ratio of 3:1 to be optimal, with SC- $\beta$ cells sitting on top of microtubule networks formed by the ECs.

Current protocols produce SC- $\beta$ cells that resemble their in vivo counterparts in many important parameters but are still different in many important aspects. While SC- $\beta$ cells are capable of undergoing glucose-stimulated insulin secretion and controlling blood sugar levels in mice, how glucose-responsive the cells are and how much insulin the cells secrete is still lower than primary cadaveric human islets $[4-6,12,14]$. SC- $\beta$ cells express many markers found in primary cadaveric human islets, but several genes associated with maturation continue to be under expressed, such as MAFA and UCN3 $[5,14,15]$. We hope our reported platform for assembling key islet components enables future studies to identify the parameters to make more mature SC- $\beta$ cells in tissue engineered islets. A practical feature of our platform is that it can be achieved without specialized reagents, equipment, or training, which will facilitate future studies and is in contrast with current SC- $\beta$ cell culture methodologies $[5,12]$.

Approaches have been developed in order to generate SC- $\beta$ cell-containing aggregates that better resemble native islets. Optimization of the timing and combinations of soluble small molecules and growth factors have led to increases in differentiation yield [5]. Resizing of clusters has led to increased function both in vitro and in vivo [5, 6, 14, 16], in part by limiting hypoxia [16]. Sorting based on a transgenic reporter [6] or surface marker [14] has allowed further increases in the purity of SC- $\beta$ cells to better define the cellular population present in aggregates. Combining 3D printing with fibrin gels has better enabled transplantation of resized SC- $\beta$ cell clusters [16]. Addressing these differences and inefficiencies will bring stem cell technology closer to clinical translation and increase our understanding of $\beta$ cell biology and diabetes pathology.

While we did not find success with several approaches that we attempted, alternative methodologies could be developed to assemble ECs and SC- $\beta$ cells. Candiello et al. reported a system 
of combining ECs with hESCs differentiated to insulin-producing cells [17] but only achieved insulin secretion per cell that was order $10^{2}$ lower than achieved with our platform here. We recently used microwells to resize and enable embedding of SC- $\beta$ cell aggregates into fibrin gels within a 3D-printed macroporous device before transplantation, but introduction of ECs was not studied [16].

Tissue engineered islet organoids have value in diabetes cell replacement therapy and drug screening. Currently a major challenge in the field of diabetes cell replacement therapy is sourcing of sufficient numbers of glucose-responsive insulin-secreting $\beta$ cells [18]. Differentiated hESCs offer a potentially unlimited number of cells for this purpose [19], and this approach is enhanced by improving the maturation of the generated SC- $\beta$ cells [20]. The inclusion of endothelial cells with SC- $\beta$ cells could be combined with macroporous scaffolds that enable retrievability $[16,21]$ or other beneficial materials [22-26] to develop a more comprehensive transplantation strategy for diabetes. An alternative cell type to SC- $\beta$ cells are earlier pancreatic progenitors derived from hESCs. These are currently being explored for cell replacement therapy, as these cells can spontaneously differentiate into SC- $\beta$ cells after transplantation over the course of months [3, 27-29], but the mechanism of this maturation process is unknown and differs based on rodent species [27]. SC- $\beta$ cells or earlier progenitors, particularly derived from diabetic patients through an induced pluripotent stem cell (iPSC) intermediate, are currently being studied for disease modeling and drug screening purposes [3, 30-41]. These studies would benefit from a cellular assembly that more closely reflects the native islet microenvironment [42].

\section{Conclusions}

Our findings show that assembly of SC- $\beta$ cells with ECs will only occur under specific culture conditions. Spontaneous aggregation into clusters, assembly on two-dimensional convention tissue culture plastic, and plating on top of collagen 1 gels were unable to achieve assembly. However, we observed that dispersing and plating SC- $\beta$ cells with ECs in a 3:1 ratio on-top of Matrigel provided the greatest assembly. These assembled islet organoids were able to undergo glucose-stimulated insulin secretion and expressed a panel of $\beta$ cell markers. Our described approach provides a platform the 
study of key microenvironmental components for development of tissue engineered islet for diabetes cell replacement therapy and drug screening.

\section{Acknowledgements}

This work was supported by the NIH (R01DK114233), JDRF Career Development Award (5-CDA-2017391-A-N), Washington University Center of Regenerative Medicine, and startup funds from Washington University School of Medicine Department of Medicine. L.V.C. was supported by the NIH (R25GM103757). Microscopy was performed through the Washington University Center for Cellular Imaging (WUCCl), which is supported by Washington University School of Medicine, CDI (CDI-CORE2015-505) and the Foundation for Barnes-Jewish Hospital (3770). The Washington University Diabetes Research Center (P30DK020579) provided support for the microscopy. We thank Nicholas White and Shriya Swaminathan for technical assistance.

\section{Disclosure Statement}

L.V.C., J.S., and J.R.M. are inventors are patent filings for the stem cell technology.

\section{References}

[1] M.D. Bellin, F.B. Barton, A. Heitman, J.V. Harmon, R. Kandaswamy, A.N. Balamurugan, D.E. Sutherland, R. Alejandro, B.J. Hering, Potent induction immunotherapy promotes longterm insulin independence after islet transplantation in type 1 diabetes, Am J Transplant 12(6) (2012) 1576-83.

[2] M. McCall, A.M. Shapiro, Update on islet transplantation, Cold Spring Harb Perspect Med 2(7) (2012) a007823.

[3] J.R. Millman, C. Xie, A. Van Dervort, M. Gurtler, F.W. Pagliuca, D.A. Melton, Generation of stem cell-derived beta-cells from patients with type 1 diabetes, Nat Commun 7 (2016) 11463.

[4] F.W. Pagliuca, J.R. Millman, M. Gurtler, M. Segel, A. Van Dervort, J.H. Ryu, Q.P. Peterson, D. Greiner, D.A. Melton, Generation of functional human pancreatic beta cells in vitro, Cell 159(2) (2014) 428-39.

[5] L. Velazco-Cruz, J. Song, K.G. Maxwell, M.M. Goedegebuure, P. Augsornworawat, N.J. Hogrebe, J.R. Millman, Acquisition of Dynamic Function in Human Stem Cell-Derived beta Cells, Stem cell reports 12(2) (2019) 351-365.

[6] G.G. Nair, J.S. Liu, H.A. Russ, S. Tran, M.S. Saxton, R. Chen, C. Juang, M.L. Li, V.Q. Nguyen, S. Giacometti, S. Puri, Y. Xing, Y. Wang, G.L. Szot, J. Oberholzer, A. Bhushan, M. 
Hebrok, Recapitulating endocrine cell clustering in culture promotes maturation of human stem-cell-derived beta cells, Nature cell biology 21 (2) (2019) 263-274.

[7] H.A. Russ, A.V. Parent, J.J. Ringler, T.G. Hennings, G.G. Nair, M. Shveygert, T. Guo, S. Puri, L. Haataja, V. Cirulli, R. Blelloch, G.L. Szot, P. Arvan, M. Hebrok, Controlled induction of human pancreatic progenitors produces functional beta-like cells in vitro, The EMBO journal 34(13) (2015) 1759-72.

[8] Z. Ghazizadeh, D.I. Kao, S. Amin, B. Cook, S. Rao, T. Zhou, T. Zhang, Z. Xiang, R. Kenyon, O. Kaymakcalan, C. Liu, T. Evans, S. Chen, ROCKII inhibition promotes the maturation of human pancreatic beta-like cells, Nat Commun 8(1) (2017) 298.

[9] F.W. Pagliuca, D.A. Melton, How to make a functional beta-cell, Development (Cambridge, England) 140(12) (2013) 2472-83.

[10] M. Kragl, E. Lammert, Basement membrane in pancreatic islet function, Adv Exp Med Biol 654 (2010) 217-34.

[11] J.C. Stendahl, D.B. Kaufman, S.I. Stupp, Extracellular matrix in pancreatic islets: relevance to scaffold design and transplantation, Cell Transplant 18(1) (2009) 1-12. [12] A. Rezania, J.E. Bruin, P. Arora, A. Rubin, I. Batushansky, A. Asadi, S. O'Dwyer, N. Quiskamp, M. Mojibian, T. Albrecht, Y.H. Yang, J.D. Johnson, T.J. Kieffer, Reversal of diabetes with insulin-producing cells derived in vitro from human pluripotent stem cells, Nature biotechnology 32(11) (2014) 1121-33.

[13] Z. Mamdouh, G.E. Kreitzer, W.A. Muller, Leukocyte transmigration requires kinesinmediated microtubule-dependent membrane trafficking from the lateral border recycling compartment, J Exp Med 205(4) (2008) 951-66.

[14] A. Veres, A.L. Faust, H.L. Bushnell, E.N. Engquist, J.H. Kenty, G. Harb, Y.C. Poh, E. Sintov, M. Gurtler, F.W. Pagliuca, Q.P. Peterson, D.A. Melton, Charting cellular identity during human in vitro beta-cell differentiation, Nature 569(7756) (2019) 368-373.

[15] Q.P. Peterson, F.W. Pagliuca, D.A. Melton, J.R. Millman, M.S. Segel, M. Gurtler, SC- $\beta$ cells and compositions and methods for generating the same., HRVY-031-WO1 (2014). [16] J. Song, J.R. Millman, Economic 3D-printing approach for transplantation of human stem cell-derived beta-like cells, Biofabrication 9(1) (2016) 015002.

[17] J. Candiello, T.S.P. Grandhi, S.K. Goh, V. Vaidya, M. Lemmon-Kishi, K.R. Eliato, R. Ros, P.N. Kumta, K. Rege, I. Banerjee, 3D heterogeneous islet organoid generation from human embryonic stem cells using a novel engineered hydrogel platform, Biomaterials 177 (2018) 2739.

[18] G.C. Weir, C. Cavelti-Weder, S. Bonner-Weir, Stem cell approaches for diabetes: towards beta cell replacement, Genome Med 3(9) (2011) 61.

[19] J.R. Millman, F.W. Pagliuca, Autologous Pluripotent Stem Cell-Derived beta-Like Cells for Diabetes Cellular Therapy, Diabetes 66(5) (2017) 1111-1120.

[20] A.A. Tomei, C. Villa, C. Ricordi, Development of an encapsulated stem cell-based therapy for diabetes, Expert Opin Biol Ther 15(9) (2015) 1321-36.

[21] E. Pedraza, A.C. Brady, C.A. Fraker, R.D. Molano, S. Sukert, D.M. Berman, N.S. Kenyon, A. Pileggi, C. Ricordi, C.L. Stabler, Macroporous three-dimensional PDMS scaffolds for extrahepatic islet transplantation, Cell Transplant 22(7) (2013) 1123-35.

[22] M. Najjar, V. Manzoli, M. Abreu, C. Villa, M.M. Martino, R.D. Molano, Y. Torrente, A. Pileggi, L. Inverardi, C. Ricordi, J.A. Hubbell, A.A. Tomei, Fibrin gels engineered with proangiogenic growth factors promote engraftment of pancreatic islets in extrahepatic sites in mice, Biotechnology and bioengineering 112(9) (2015) 1916-26. 
[23] S.D. Sackett, D.M. Tremmel, F. Ma, A.K. Feeney, R.M. Maguire, M.E. Brown, Y. Zhou, X. Li, C. O'Brien, L. Li, W.J. Burlingham, J.S. Odorico, Extracellular matrix scaffold and hydrogel derived from decellularized and delipidized human pancreas, Sci Rep 8(1) (2018) 10452.

[24] D.M. Tremmel, J.S. Odorico, Rebuilding a better home for transplanted islets, Organogenesis 14(4) (2018) 163-168.

[25] K. Jiang, D. Chaimov, S.N. Patel, J.P. Liang, S.C. Wiggins, M.M. Samojlik, A. Rubiano, C.S. Simmons, C.L. Stabler, 3-D physiomimetic extracellular matrix hydrogels provide a supportive microenvironment for rodent and human islet culture, Biomaterials 198 (2019) 3748.

[26] M.M. Coronel, J.P. Liang, Y. Li, C.L. Stabler, Oxygen generating biomaterial improves the function and efficacy of beta cells within a macroencapsulation device, Biomaterials 210 (2019) $1-11$.

[27] J.E. Bruin, A. Asadi, J.K. Fox, S. Erener, A. Rezania, T.J. Kieffer, Accelerated Maturation of Human Stem Cell-Derived Pancreatic Progenitor Cells into Insulin-Secreting Cells in Immunodeficient Rats Relative to Mice, Stem cell reports 5(6) (2015) 1081-1096. [28] E. Kroon, L. Martinson, K. Kadoya, A. Bang, O. Kelly, S. Eliazer, H. Young, M. Richardson, N. Smart, J. Cunningham, A. Agulnick, K. D'Amour, M. Carpenter, E. Baetge, Pancreatic endoderm derived from human embryonic stem cells generates glucose-responsive insulin-secreting cells in vivo, Nature biotechnology 26(185fd244-a11e-4f3c-b3bc44ad1daacb41) (2008) 443-495.

[29] A. Rezania, J.E. Bruin, M.J. Riedel, M. Mojibian, A. Asadi, J. Xu, R. Gauvin, K. Narayan, F. Karanu, J.J. O'Neil, Z. Ao, G.L. Warnock, T.J. Kieffer, Maturation of human embryonic stem cell-derived pancreatic progenitors into functional islets capable of treating pre-existing diabetes in mice, Diabetes 61(8) (2012) 2016-29.

[30] D. Balboa, J. Saarimaki-Vire, D. Borshagovski, M. Survila, P. Lindholm, E. Galli, S. Eurola, J. Ustinov, H. Grym, H. Huopio, J. Partanen, K. Wartiovaara, T. Otonkoski, Insulin mutations impair beta-cell development in a patient-derived iPSC model of neonatal diabetes, eLife 7 (2018).

[31] S. Ma, R. Viola, L. Sui, V. Cherubini, F. Barbetti, D. Egli, beta Cell Replacement after Gene Editing of a Neonatal Diabetes-Causing Mutation at the Insulin Locus, Stem cell reports 11(6) (2018) 1407-1415.

[32] X. Wang, M. Sterr, Ansarullah, I. Burtscher, A. Böttcher, J. Beckenbauer, J. Siehler, T. Meitinger, H.-U. Häring, H. Staiger, F.M. Cernilogar, G. Schotta, M. Irmler, J. Beckers, C.V.E. Wright, M. Bakhti, H. Lickert, Point mutations in the PDX1 transactivation domain impair human $\beta$-cell development and function, Molecular metabolism (2019).

[33] R. Maehr, S. Chen, M. Snitow, T. Ludwig, L. Yagasaki, R. Goland, R.L. Leibel, D.A. Melton, Generation of pluripotent stem cells from patients with type 1 diabetes, Proceedings of the National Academy of Sciences of the United States of America 106(37) (2009) 15768-73. [34] T. Thatava, Y.C. Kudva, R. Edukulla, K. Squillace, J.G. De Lamo, Y.K. Khan, T. Sakuma, S. Ohmine, A. Terzic, Y. Ikeda, Intrapatient variations in type 1 diabetes-specific iPS cell differentiation into insulin-producing cells, Mol Ther 21(1) (2013) 228-39.

[35] L. Shang, H. Hua, K. Foo, H. Martinez, K. Watanabe, M. Zimmer, D.J. Kahler, M. Freeby, W. Chung, C. LeDuc, R. Goland, R.L. Leibel, D. Egli, beta-cell dysfunction due to increased ER stress in a stem cell model of Wolfram syndrome, Diabetes 63(3) (2014) 923-33.

[36] H. Hua, L. Shang, H. Martinez, M. Freeby, M.P. Gallagher, T. Ludwig, L. Deng, E. Greenberg, C. Leduc, W.K. Chung, R. Goland, R.L. Leibel, D. Egli, iPSC-derived beta cells model diabetes due to glucokinase deficiency, The Journal of clinical investigation 123(7) (2013) 3146-53. 
[37] M. Yamada, B. Johannesson, I. Sagi, L.C. Burnett, D.H. Kort, R.W. Prosser, D. Paull, M.W. Nestor, M. Freeby, E. Greenberg, R.S. Goland, R.L. Leibel, S.L. Solomon, N.

Benvenisty, M.V. Sauer, D. Egli, Human oocytes reprogram adult somatic nuclei of a type 1 diabetic to diploid pluripotent stem cells, Nature 510(7506) (2014) 533-6.

[38] L. Sui, N. Danzl, S.R. Campbell, R. Viola, D. Williams, Y. Xing, Y. Wang, N. Phillips, G. Poffenberger, B. Johannesson, J. Oberholzer, A.C. Powers, R.L. Leibel, X. Chen, M. Sykes, D. Egli, beta-Cell Replacement in Mice Using Human Type 1 Diabetes Nuclear Transfer Embryonic Stem Cells, Diabetes 67(1) (2018) 26-35.

[39] Y.C. Kudva, S. Ohmine, L.V. Greder, J.R. Dutton, A. Armstrong, J.G. De Lamo, Y.K. Khan, T. Thatava, M. Hasegawa, N. Fusaki, J.M.W. Slack, Y. Ikeda, Transgene-Free DiseaseSpecific Induced Pluripotent Stem Cells from Patients with Type 1 and Type 2 Diabetes, Stem Cell Transl Med 1(6) (2012) 451-461.

[40] S. Simsek, T. Zhou, C.L. Robinson, S.Y. Tsai, M. Crespo, S. Amin, X. Lin, J. Hon, T. Evans, S. Chen, Modeling Cystic Fibrosis Using Pluripotent Stem Cell-Derived Human Pancreatic Ductal Epithelial Cells, Stem Cells Transl Med 5(5) (2016) 572-9.

[41] A.K. Teo, R. Windmueller, B.B. Johansson, E. Dirice, P.R. Njolstad, E. Tjora, H. Raeder, R.N. Kulkarni, Derivation of human induced pluripotent stem cells from patients with maturity onset diabetes of the young, The Journal of biological chemistry 288(8) (2013) 5353-6. [42] R. Olsson, P.O. Carlsson, The pancreatic islet endothelial cell: emerging roles in islet function and disease, Int J Biochem Cell Biol 38(5-6) (2006) 710-4. 
bioRxiv preprint doi: https://doi.org/10.1101/653378; this version posted May 29, 2019. The copyright holder for this preprint (which was not certified by peer review) is the author/funder, who has granted bioRxiv a license to display the preprint in perpetuity. It is made available under aCC-BY-NC-ND 4.0 International license.

\section{Figures}


A

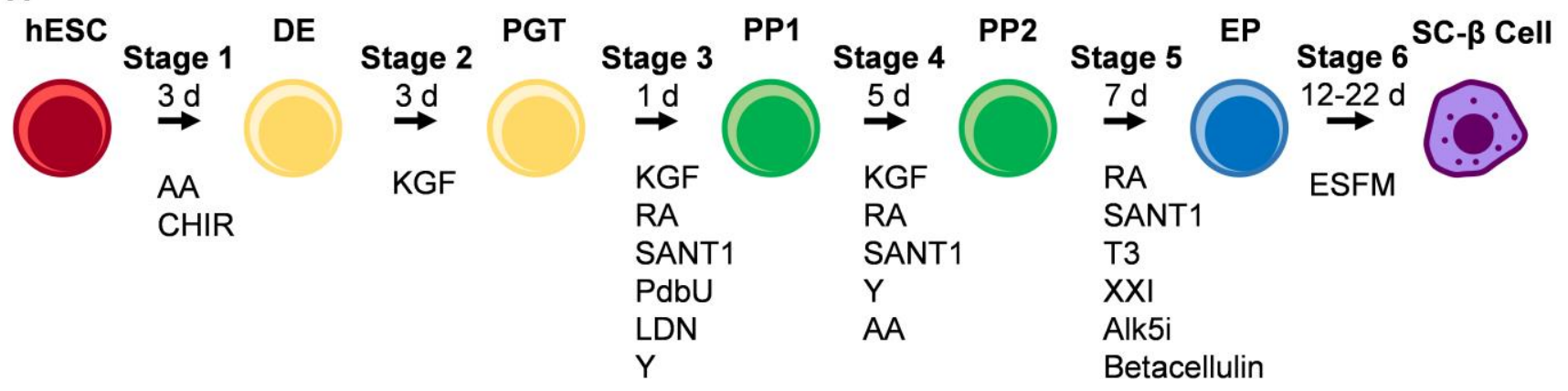

B

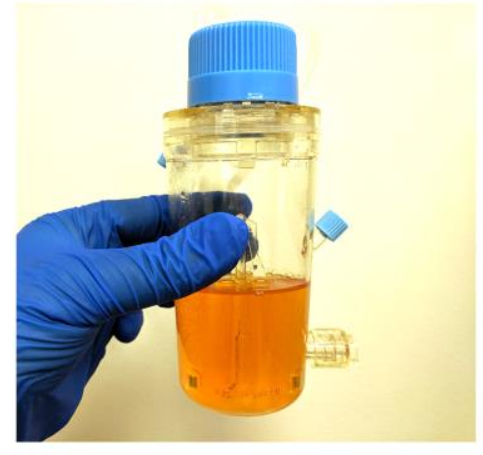

C

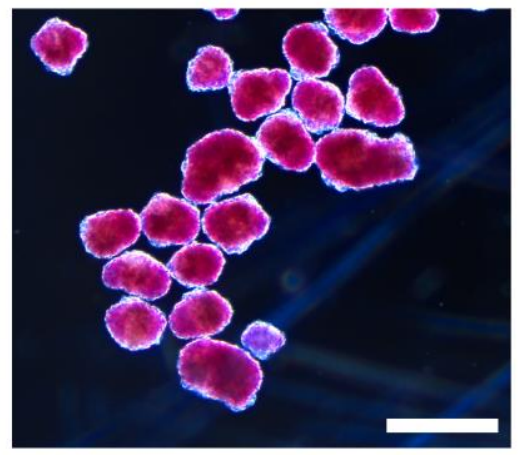

D

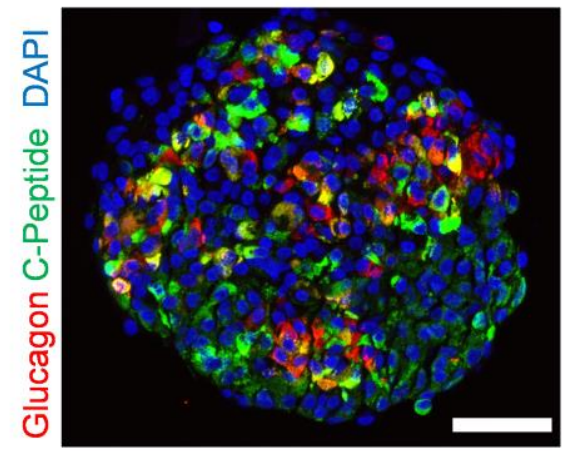

Fig. 1. Generation of SC- $\beta$ cells. A. Schematic diagram of differentiation process to generate SC- $\beta$ cells. B. Image of spinner flask approach used to grow and differentiate hESCs to SC- $\beta$ cells. C. Micrograph of Stage 6 clusters stained with dithizone, a dye that stains $\beta$ cells red, imaged under bright field. Scale bar $=500 \mu \mathrm{m}$. D. Immunostaining of Stage 6 cluster sectioned and stained for C-peptide and glucagon. Scale bar $=100 \mu \mathrm{m}$. DE, definitive endoderm; PGT, primitive gut tube; PP1, pancreatic progenitor 1; PP2, pancreatic progenitor 2; EP, endocrine progenitor; AA, activin A; CHIR, CHIR9901; KGF, keratinocyte growth factor; RA, retinoic acid; Y, Y27632; LDN, LDN193189; PdbU, phorbol 12,13dibutyrate; T3, triiodothyronine; Alk5i, Alk5 inhibitor type II; ESFM, enriched serum-free medium. 
A

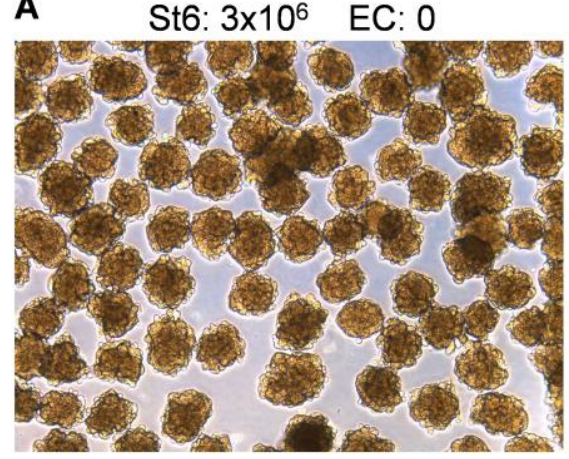

St6: $2.5 \times 10^{6} \quad$ EC: $0.5 \times 10^{6}$

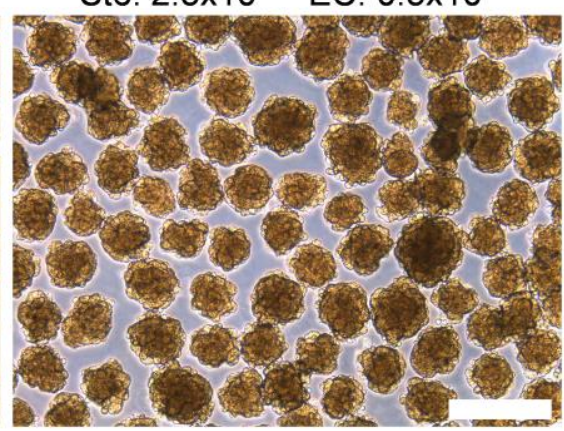

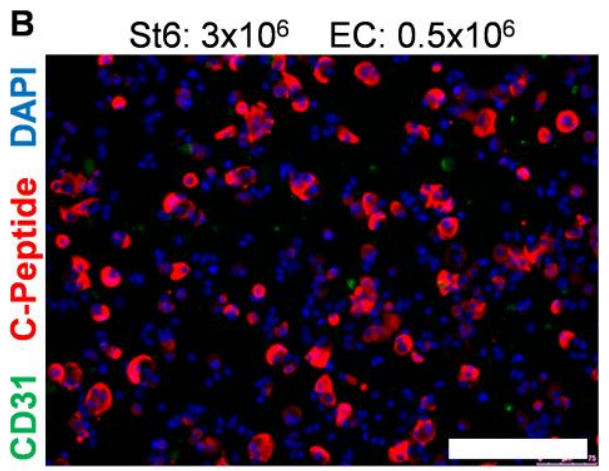

Fig. 2. ECs and SC- $\beta$ cells do not assemble in suspension culture. A. Micrographs of unstained reaggregated Stage 6 clusters with or without the addition of ECs. Scale bar $=400 \mu \mathrm{m}$. B. Immunostaining of Stage 6 clusters reaggregated with ECs dispersed and plated for assessment. Scale bar $=150 \mu \mathrm{m}$. 
bioRxiv preprint doi: https://doi.org/10.1101/653378; this version posted May 29, 2019. The copyright holder for this preprint (which was not certified by peer review) is the author/funder, who has granted bioRxiv a license to display the preprint in perpetuity. It is made available under aCC-BY-NC-ND 4.0 International license.

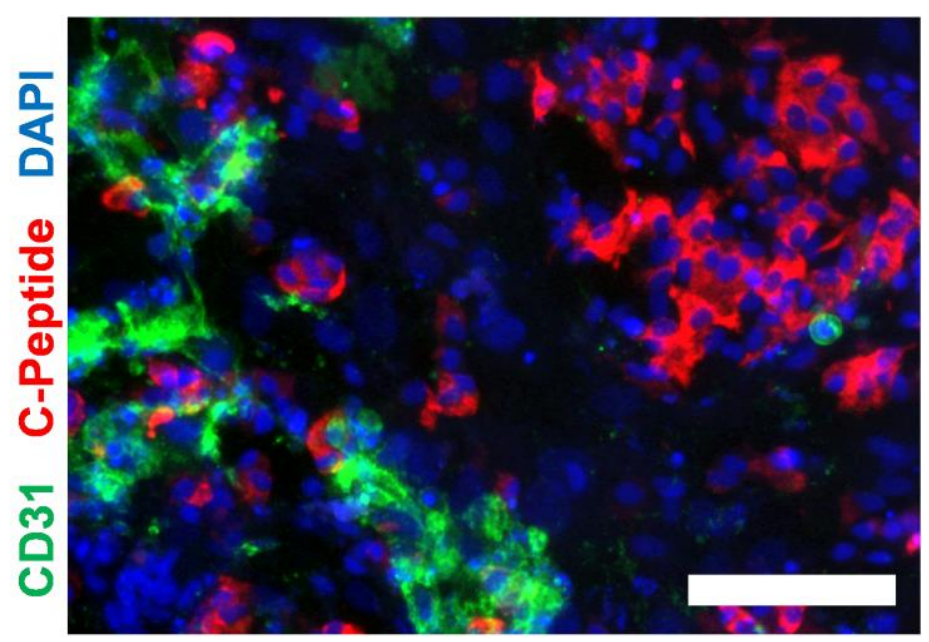

Fig. 3. ECs and SC- $\beta$ cells do not assemble in two-dimensional culture. Immunostaining of Stage 6 clusters mixed with ECs and plated for assembly. Scale bar $=150 \mu \mathrm{m}$. 
bioRxiv preprint doi: https://doi.org/10.1101/653378; this version posted May 29, 2019. The copyright holder for this preprint (which was not certified by peer review) is the author/funder, who has granted bioRxiv a license to display the preprint in perpetuity. It is made available under aCC-BY-NC-ND 4.0 International license.
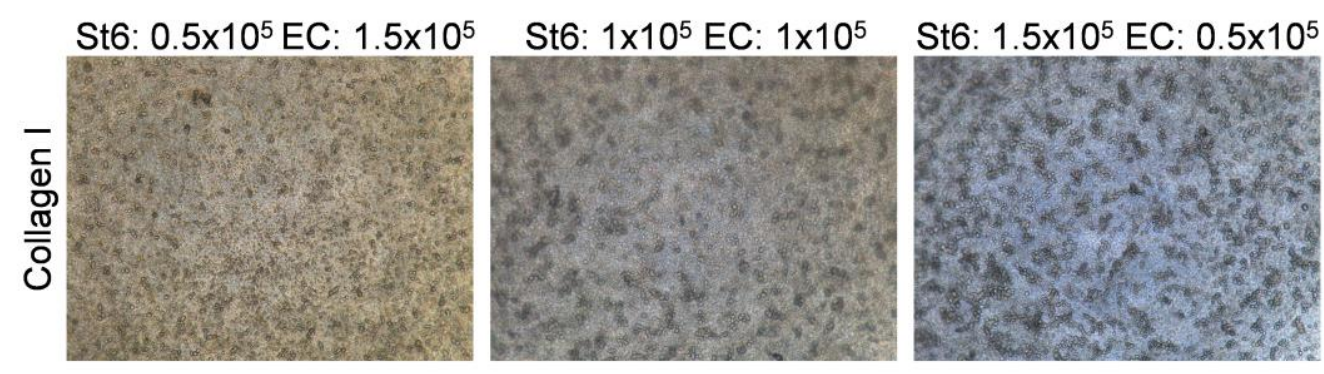

St6: $2 \times 10^{5} \mathrm{EC}: 0$
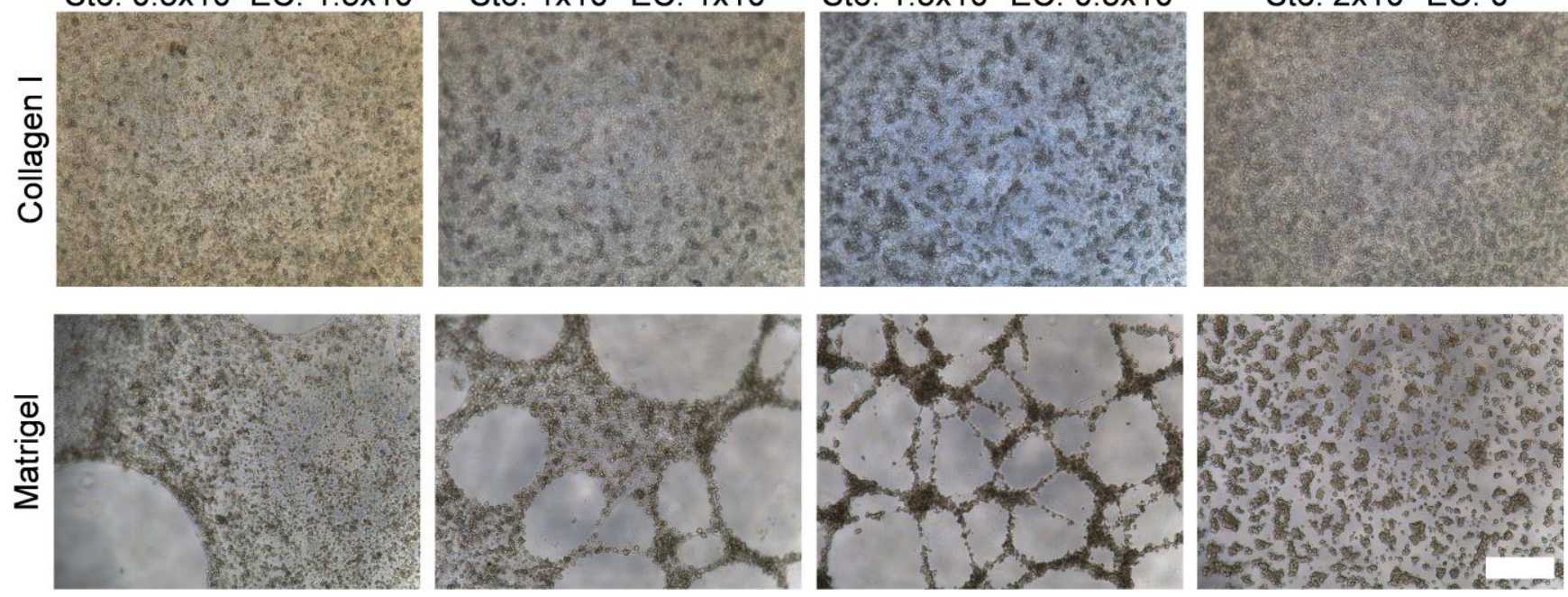

Fig. 4. ECs and SC- $\beta$ cells assemble on top of Matrigel but not collagen 1 gels. Shown are micrographs of varying ratios of ECs and SC- $\beta$ cells after $24 \mathrm{hr}$. Scale bar $=400 \mu \mathrm{m}$. 

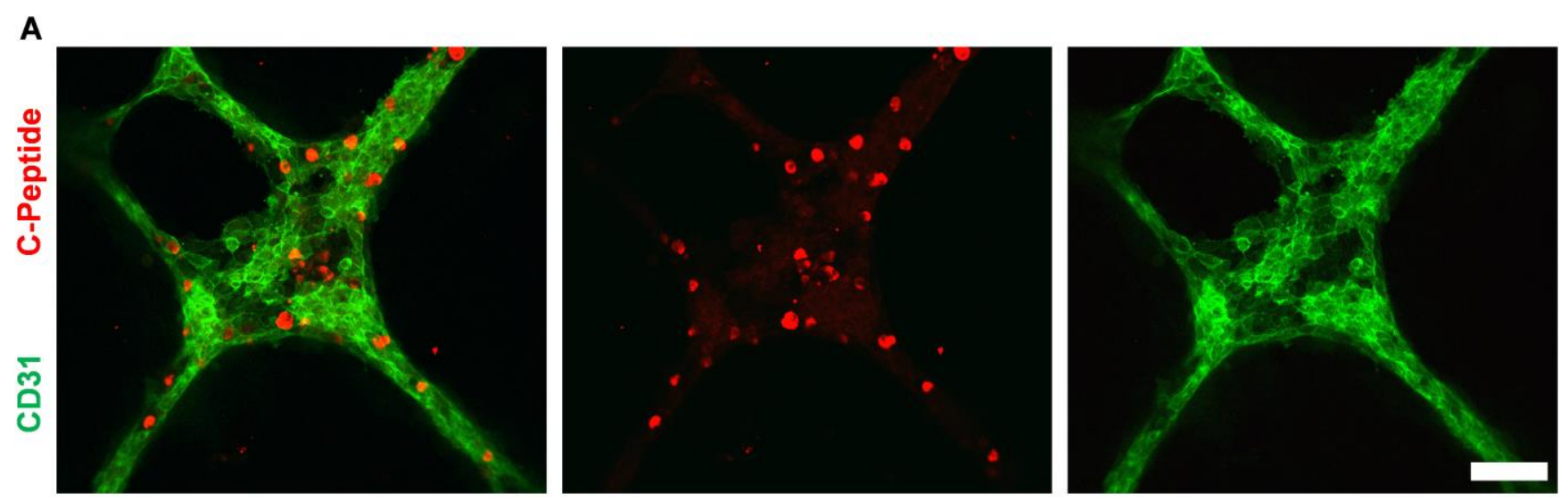

B

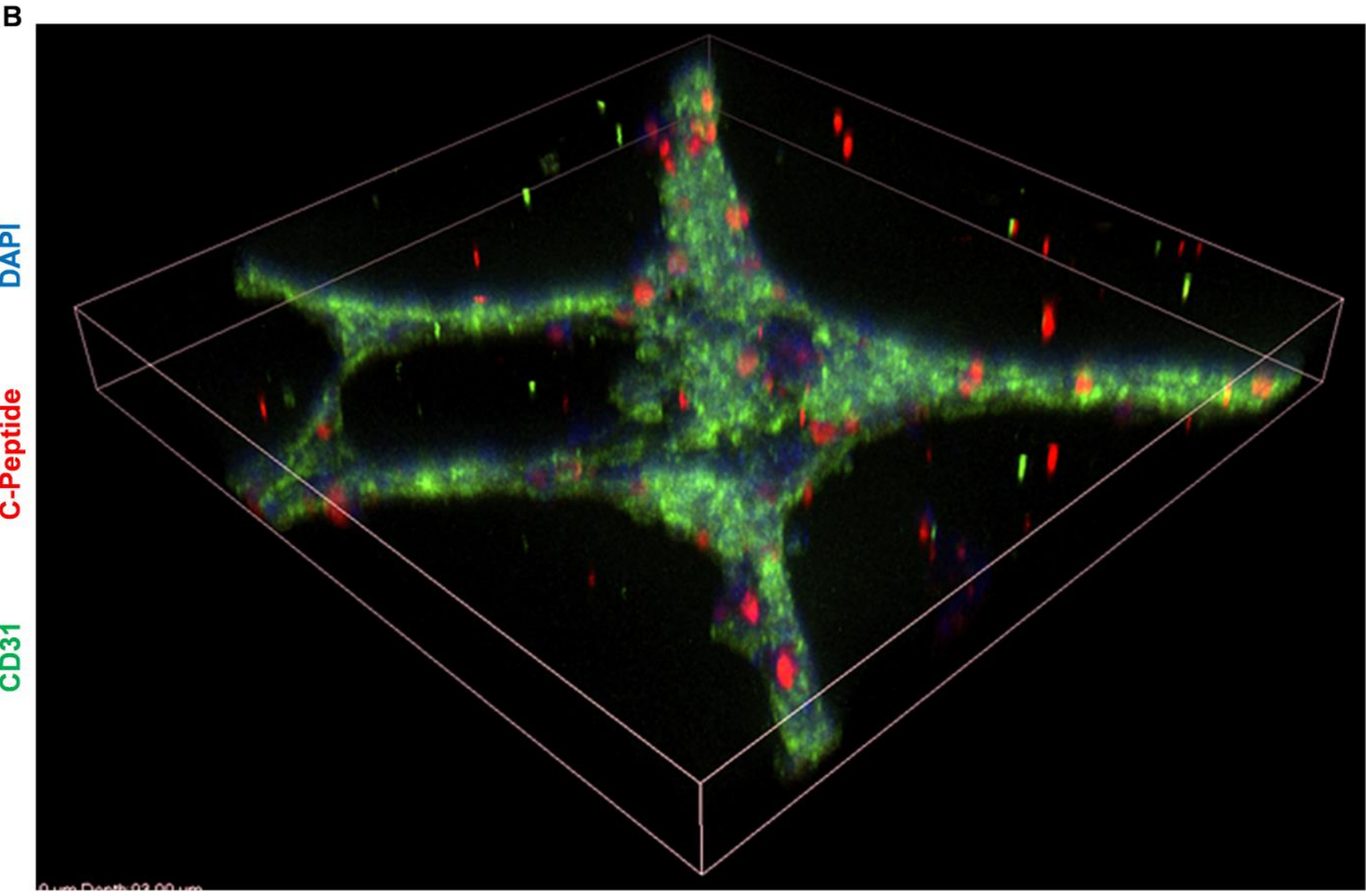

C

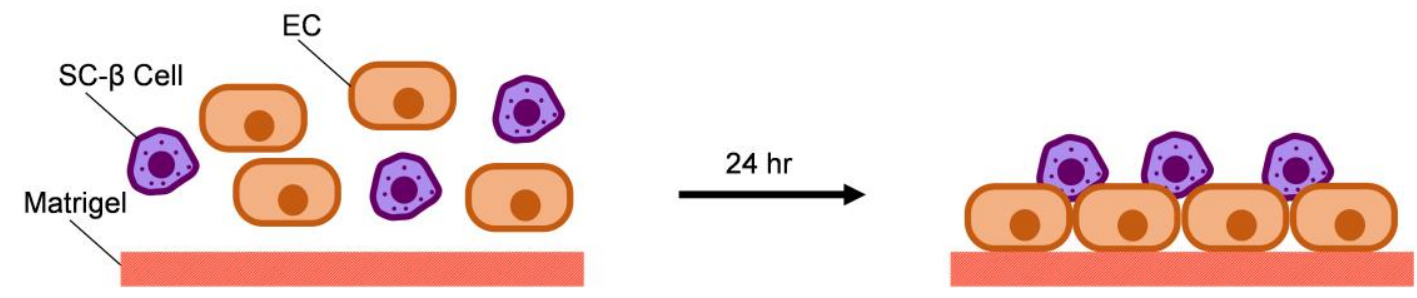

Fig. 5. Immunostaining assessment of ECs and SC- $\beta$ cells assemble formed on Matrigel. A. En face image of immunostained organoid. Scale bar $=100 \mu \mathrm{m}$. B. Tilted view of constructed three-dimensional 
bioRxiv preprint doi: https://doi.org/10.1101/653378; this version posted May 29, 2019. The copyright holder for this preprint (which was not certified by peer review) is the author/funder, who has granted bioRxiv a license to display the preprint in perpetuity. It is made available under aCC-BY-NC-ND 4.0 International license.

z-stacks. The shown dimensions are 636.4 × 636.4 × $93 \mu \mathrm{m}$. C. Schematic cartoon of islet organoid assembly. 


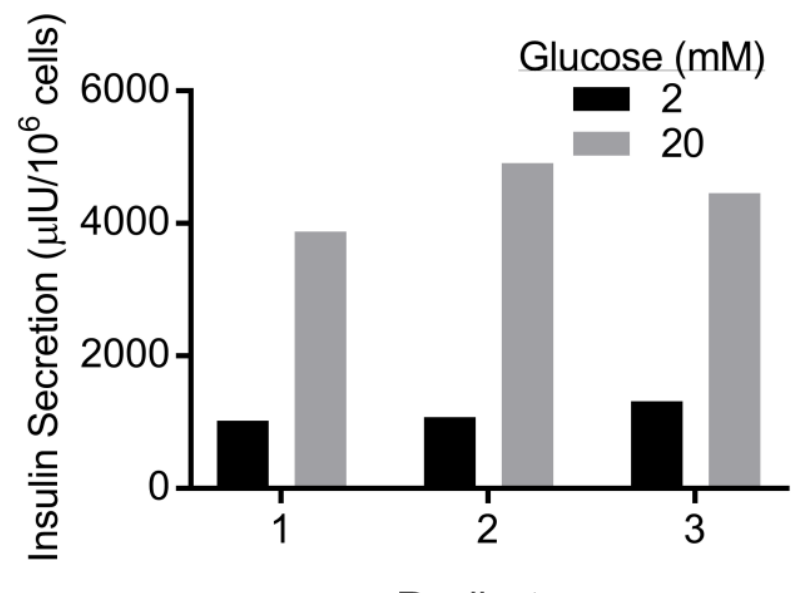

Replicates

Fig. 6. Glucose-stimulated insulin secretion assay of EC and SC- $\beta$ cell assembly formed on Matrigel.

Three biological replicates are plotted separately. 

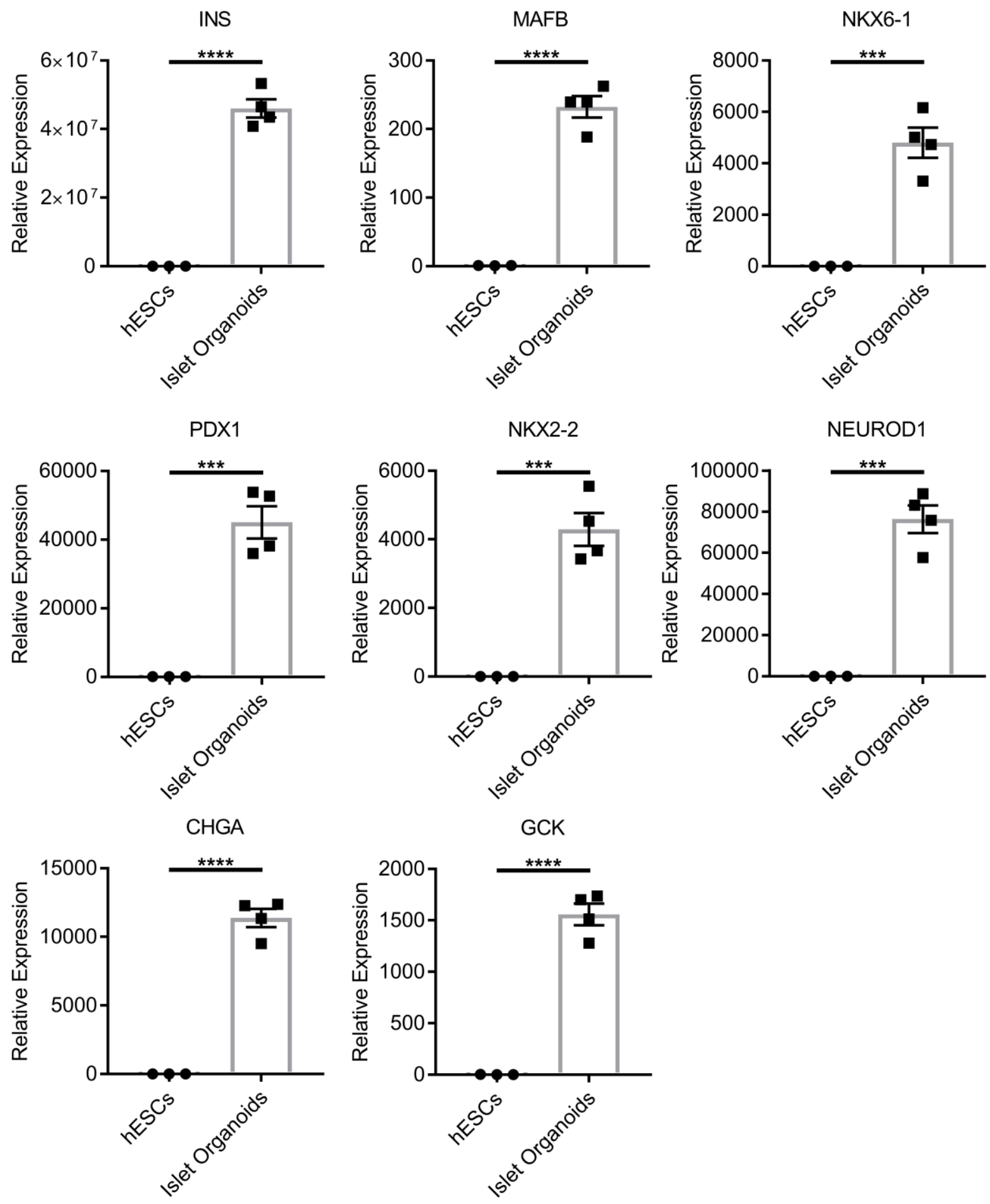

Fig. 7. Gene expression analysis of EC and SC- $\beta$ cell assembly formed on Matrigel. Eight genes associated with the $\beta$ cells were measured and comparing the islet organoid $(n=4)$ to undifferentiated hESCs $(n=3) .{ }^{* * *} p<0.001$ and ${ }^{* * * *} p<0.0001$ by two-way unpaired $t$-test. 